\title{
A CONTROL METHOD FOR DRIVING DUAL PERMANENT MAGNET SYNCHRONOUS MOTORS FED BY SINGLE MATRIX CONVERTER
}

\author{
Yurdagül Benteșen Yakut, Sedat Sünter, Mehmet Özdemir
}

Preliminary communication

In this study, a control method is created to drive two parallel-connected permanent magnet synchronous motors fed by a single converter. Matrix converter used in this work provides ac-ac conversion in one stage. The matrix converter model and d-q model of dual PMSMs are performed in Matlab/Simulink. In industrial applications containing dual motors fed from a single converter, volume and weight of the drive system decreases, power electronics switches and other components are reduced and the installation cost decreases. Because of these advantages, many methods are being developed by researchers to control the dual motor drives. In this study, the motor control has been performed by using the average speed method. Control of dual permanent magnet synchronous motors with a single converter is implemented with ANFIS-based neural fuzzy controllers. All parameters of the motors are taken equal since two identical permanent magnet synchronous motors are considered. Two various operation conditions are investigated in the simulation. In the first case, one of the identical motors is operated on no-load, while the other one is operated with the rated load. In the second case, each motor is operated with various load torques varying with the time. Corresponding simulation results have been presented to show the performance of the drive system.

Keywords: dual motor drives; matrix converter; neural fuzzy; PMSM; variable load; vector control

Metoda upravljanja pogonom sinhronih motora s dvostrukim trajnim magnetom napajanih pretvaračem s jednom matricom

Prethodno priopćenje

U ovom je radu predstavljena metoda upravljanja pogonom dva sinhrona motora s paralelno povezanim trajnim magnetom, napajana jednim pretvaračem. Ovdje primijenjeni matrični konverter omogućuje ac-ac konverziju u jednom stupnju. Model matričnog konvertera i d-q model dvostrukih PMSMs izvode se u Matlab/Simulink-u. U industrijskim primjenama s dvostrukim motorima napajanim iz jedinstvenog pretvarača, smanjuje se volumen i težina pogonskog sustava, reduciraju se energetsko elektronički prekidači i druge komponente i smanjuju instalacijski troškovi. Zbog ovih su prednosti razvijene mnoge metode za upravljanje dvostrukim motornim pogonom. U ovom se istraživanju upravljanje motorom izvodi primjenom metode prosječne brzine. Upravljanje sinhronim motorima s dvostrukim permanentnim magnetom s jednim pretvaračem provodi se s neuronskim fuzzy regulatorima na bazi ANFIS-a. Svi se parametri motora smatraju jednakima budući da se razmatraju dva identična sinhrona motora s permanentnim magnetima. U simulaciji se istražuju dva različita uvjeta rada. U prvom slučaju, jedan od identičnih motora radi bez opterećenja, a drugi s nazivnim opterećenjem. U drugom slučaju, svaki motor radi s različitim momentima opterećenja koji variraju s vremenom. Prikazani su odgovarajući rezultati simulacije kako bi se pokazala učinkovitost pogonskog sustava.

Ključne riječi: dvostruki motorni pogon; matrični konverter; neuronski fuzzy; PMSM; promjenjivo opterećenje; vektorska regulacija

\section{Introduction}

Control and conversion of electrical energy is one of the most significant processes in electrical engineering. With the rapid developments in power electronics converters and particularly in semiconductor power components, major developments were observed in controlling the electrical energy. One of the members of power converter family is the matrix converter which performs direct conversion from ac to ac with variable voltage and frequency $[1,2]$.

Matrix converter is made up of bidirectional switches arranged as a matrix [3]. These devices switch the constant supply voltage and form the output voltage at variable amplitudes and frequencies $[4,5]$. Output voltage has amplitude of a certain proportion of the input voltage amplitude. Matrix converters can be controlled using Venturini, Scalar or space vector control algorithms. In this study, matrix converter switches have been controlled by Venturini control algorithm.

In a permanent magnet synchronous motor (PMSM), the rotor windings are replaced with permanent magnets. PMSMs have started to be commonly used in various areas such as home applicants and automotive industry, particularly in speed and position control applications, due to their efficiency, longevity and high power density compared to other electric motors. Therefore, high performance control of these motors is one of the most investigated topics nowadays. Synchronous machines are made up of phase windings placed in stator slots and permanent magnets in the rotor [5]. In the field windings, rotor copper losses are present. As magnets are used in the rotor of PMSM, these losses are reduced. Therefore, a motor with higher efficiency is produced. Copper and iron losses occur only in the stator windings. In the synchronous motor, while the stator winding named armature is fed from a three-phase ac voltage source, the field winding is fed from a dc voltage source. The excitation occurring in the field windings of synchronous machines can be accomplished with permanent magnets. Electric motors are commonly used in many industrial areas. PMSMs are today used in many applications such as servo-drive motors, robots, ship motors, tractions, electric cars, pumps, elevators, refrigerators and washing machines, etc.

Fuzzy logic controllers aim to incorporate expert experience into the required controller design for the control of a system including linguistic variables and described with fuzzy rules instead of the complex mathematical model of a system. Fuzzy systems use fuzzy sets to establish connection between input and output variables. Dr. Lotfi A. Zadeh suggested the fuzzy logic theory in 1965 to eliminate the deficiencies, difficulties and errors in the functioning of classical logic [8]. Zadeh argued in his study that the majority of human thoughts are fuzzy and imprecise. In the human thought system, 
while there are precise expressions such as hot and cold, 0 and 1 , there are also intermediate values such as cool and warm. Fuzzy logic concept considers these intermediate values in addition to precise values. Fuzzy logic is able to make calculations according to imprecise or incomplete information. In the fuzzy controller, an algorithm converting to linguistic control strategy based on expert knowledge gives better results compared to traditional algorithms. Expert knowledge is required in the process control. Expert knowledge is expressed with IF and THEN rules. If expert knowledge is unavailable in the system, mathematical model of the system, simulations, fuzzy model of the process and various learning algorithms are used in order to create the fuzzy rule base. Adaptive-network based fuzzy inference systems (ANFIS) is an artificial intelligence technique highlighting the advantageous aspects of Fuzzy Logic (FL) and Artificial Neural Networks-ANN methods and used in various fields in recent years. ANFIS model developed in 1993 by Jang uses Sugeno-type fuzzy inference system and hybrid learning algorithm [9, 10]. ANFIS consists of ANN with its structure of easily applicable learning algorithms and FL with its expert knowledge system.

Dual motor drives are used in areas requiring high power applications in industry $[11,12]$. They find more and more applications in industry nowadays. These systems allow to extend the field of high power applications or to increase their flexibility, mechanical simplicity and safety operating. However, dual motor drive requires two inverters with coordinated control, and it requires many power switches which increase the size and make system bulky. The high cost and large size of the converter make such dual motor drive configurations unattractive and economically less competitive.

In parallel-connected systems, control of the dual motors can be provided by a single converter [11]. These systems allow the mechanical area to expand or to increase the flexibility in high-power applications. Systems driven by multiple converters are large in size, have high-cost and consist of many bulky power switches. In industrial applications with dual motors fed from a single converter, the hardware size decreases, power electronics switches and other components are reduced and the installation cost decreases. In this work, matrix converters have been proposed to be used instead of inverters because of their many advantages stated earlier.

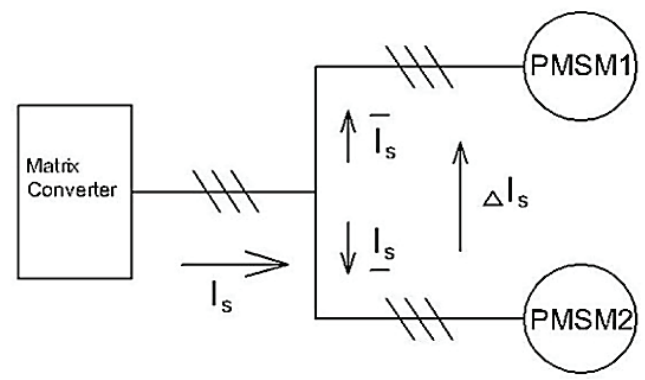

Figure 1 Block diagram of dual permanent magnet synchronous motors fed by single matrix converter

Dual motor drive systems fed by a single converter can find applications in traction and industry such as electrical railways (where two or more motors operate in parallel) and steel processing. In traction, the drive system may become unstable for some reasons such as imbalance arising among the torque and currents.

In many industrial applications, drive systems are desired to meet the demands under different speed and load conditions. A high performance system is obtained by combining PMSM with the matrix converter. Various methods have been proposed to control the dual motor drive systems. These systems can be controlled by optimum torque/current control, estimated torque control, master-slave method and average speed and current methods $[11,13 \div 16]$. In this study, the vector control of dual permanent magnet synchronous motors fed by the matrix converter is implemented using the average speed and average current methods. ANFIS-based neural fuzzy is used in the control system.

\section{Matrix converter}

Matrix converters which directly connect ac supply to an $a c$ load are made up of bidirectional switches arranged in a matrix form. In a three phase in - three phase out matrix converter there are 9 bidirectional switches arranged as a matrix [4]. By using various switching techniques, these switches enable to generate waveforms with various frequencies and amplitudes at the output that will satisfy types and requirements of the load. Output voltage waveforms are constructed by chopping the threephase input voltage waveforms at the rate of switching frequency. Venturini algorithm used in this study enables the converter to operate with unity input displacement factor. Four-quadrant operation is also inherent in the matrix converter.

Commutation in matrix converters must be provided by considering two basic rules at any times. These rules can be explained by considering two switches connected to one of the output phases of the converter. Since the converter input is a voltage source, a short circuit of the input must be avoided (Fig. 2a). In case of inductive load, an open circuit should be avoided at the output lines of the converter to prevent disconnection of the load current (Fig. 2b).

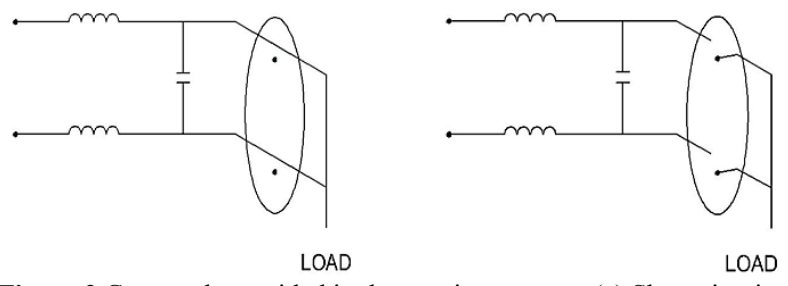

Figure 2 Cases to be avoided in the matrix converter (a) Short circuit of the input lines, (b) Open circuit of the output lines (in case of inductive load).

\subsection{Venturini modulation technique}

This control algorithm gives unlimited output frequency, sinusoidal input current and output voltage waveforms and controlled input displacement factor.

The simplified form of Venturini algorithm is suitable for real-time applications and provides a control algorithm with the unity input displacement factor. Instead of determining each time point and the zero 
crossing point of input voltage waveform, the simplified form of Venturini algorithm is identified in each sequential time in terms of three-phase input voltages. For unity power factor, conduction time of the switch placed between $\beta$ input phase and $\gamma$ output phase can be expressed as:

$$
T_{\beta \gamma}=T_{s}\left[\frac{1}{3}+\frac{2 V_{0 \gamma} V_{i \beta}}{3 V_{i m}^{2}}+\frac{2 q}{9 q_{m}} \sin \left(\omega_{i} t+\varphi_{\beta}\right) \sin \left(3 \omega_{i} t\right)\right]
$$

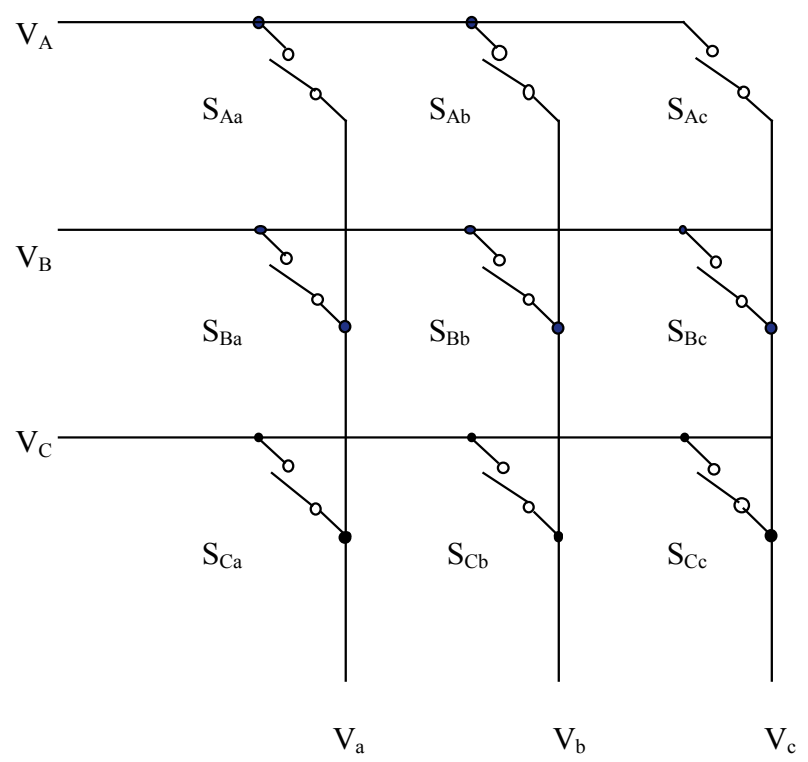

Figure 3 The structure of matrix converter with three-phase outputs and the switch layout

Where: $\varphi_{\beta}$ refers to the angle of $\mathrm{A}, \mathrm{B}, \mathrm{C}$ input phases $(0$, $2 \pi / 3,4 \pi / 3), q_{m}$ is maximum voltage ratio $(0.866), q$ is desired voltage ratio, $V_{i m}$ is peak of the input voltage, $T_{s}$ is the sampling period, $V_{i \beta}$ is the instantaneous value of the relevant input voltage phase and $\omega_{i}$ is the input angular frequency. Output voltage, $V_{0 \gamma}$ is expressed as:

$$
\begin{aligned}
V_{0 \gamma}= & q V_{i m} \cos \left(\omega_{0} t+\varphi_{\gamma}\right)-\frac{q}{6} V_{i m} \cos \left(3 \omega_{0} t\right)+ \\
& +\frac{1}{4} \frac{q}{q_{m}} V_{i m} \cos \left(3 \omega_{i} t\right)
\end{aligned}
$$

$\varphi_{\gamma}: a, b, c$ is the phase angle of output phases $(0,2 \pi / 3$, $4 \pi / 3) ; \omega_{0}$ is the output frequency. As seen in Eq. (2), the $3^{\text {rd }}$ harmonics of the input and output frequencies are present in the desired output voltage in order to obtain the possible maximum voltage ratio (0.866).

To control the output voltage of the matrix converter it is necessary to calculate the conduction times of the switch for each sampling period to get variable frequency and voltage, especially in the systems where closed loop operation is required.

In Sunter-Clare algorithm [17], the maximum values of the input voltage and output voltage must be known in order to calculate the voltage ratio, $\mathrm{q}$ in each sampling period. These values can be calculated by Eq. (3) $\div(7)$ as:

$V_{i m}^{2}=\frac{4}{9}\left(V_{A B}^{2}+V_{B C}^{2}+V_{A B} V_{B C}\right)$ $\omega_{i} t=\arctan \left(\frac{V_{B C}}{\sqrt{3}\left(\frac{2}{3} V_{A B}+\frac{1}{3} V_{B C}\right)}\right)$

$V_{0 m}^{2}=\frac{2}{3}\left(V_{a}^{2}+V_{b}^{2}+V_{c}^{2}\right)$

$\omega_{0} t=\arctan \left(\frac{V_{b}-V_{c}}{\sqrt{3} V_{a}}\right)$

$q=\sqrt{\frac{V_{0 m}^{2}}{V_{i m}^{2}}}$

\section{Modelling of PMSM}

The vector control of PMSM has a similar structure with a separately excited dc motor. In a dc motor, the torque is generated from two currents - armature and field. In PMSM, $d$ and $q$ currents which correspond to the field and torque components, respectively, are obtained in two steps. First, 3-phase are transformed into 2-phase and then they are transformed to the $d-q$ currents in the synchronous frame. By concomitant use of the matrix converter and PMSM, a highly efficient ac drive system can be obtained [17].

To control an electric motor, mathematical model of the motor must be known. In a vector-controlled ac motor drive, $d$ and $q$ currents transformed from three-phase to two-phase indicate the field and torque currents, respectively. The coordinate system is usually transformed into $\alpha-\beta$ spatially fixed reference frame by Clark transformation and to $d-q$ rotating reference frame by Park transformation as shown in Fig.4.

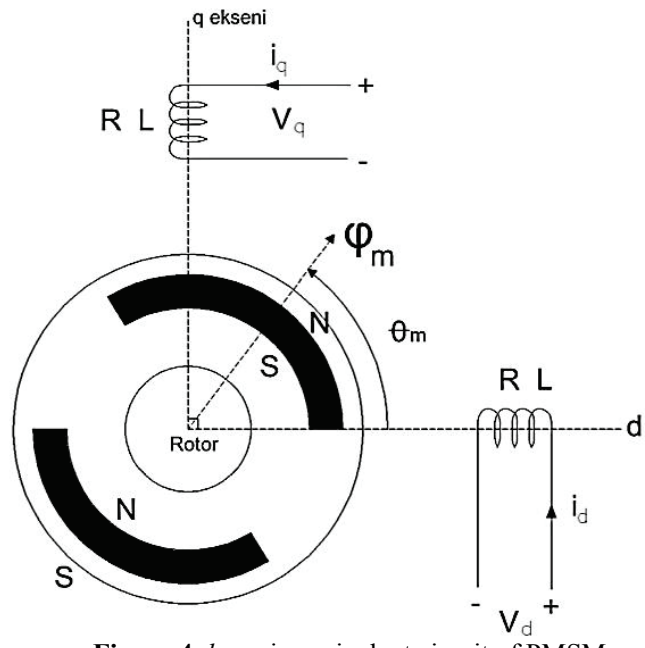

Figure $4 d-q$ axis equivalent circuit of PMSM

Following $v_{\mathrm{d}}$ and $v_{\mathrm{q}}$ equations are obtained using the $d-q$ equivalent circuit of PMSM.

Equivalent motor voltages in Fig. 4 are obtained as:

$\left[\begin{array}{l}v_{d} \\ v_{q}\end{array}\right]=\left[\begin{array}{cc}R & 0 \\ 0 & R\end{array}\right] \cdot\left[\begin{array}{l}i_{d} \\ i_{q}\end{array}\right]+\frac{\mathrm{d}}{\mathrm{d} t}\left[\begin{array}{cc}L_{d} & 0 \\ 0 & L_{q}\end{array}\right] \cdot\left[\begin{array}{l}i_{d} \\ i_{q}\end{array}\right]+\omega_{r}\left[\begin{array}{c}-\varphi_{q} \\ \varphi_{q}\end{array}\right]$

where; $v_{d}, \quad v_{q}$ represents the $d-q$ components of input voltages, respectively; $L_{d}$ and $L_{q}$ are the $d$ and $q$ axis 
inductances; $\varphi_{d}, \varphi_{q}$ are the $d$ and $q$ axis magnetic fluxes; $R$ is the stator resistance and $\omega_{r}$ is the rotor angular speed.

If Eq. (8) is rearranged and the current components in $d$ and $q$ axes of the motor are moved to the left side of the equation, Eq. (8) can be rewritten in the form of a statespace equation as:

$\left[\begin{array}{c}i_{d} \\ i_{q}\end{array}\right]=\left[\begin{array}{cc}-\frac{R}{L_{d}} & \omega_{r} \frac{L_{q}}{L_{d}} \\ -\omega_{r} \frac{L_{q}}{L_{d}} & -\frac{R}{L_{q}}\end{array}\right] \cdot\left[\begin{array}{c}i_{d} \\ i_{q}\end{array}\right]+\omega_{r}\left[\begin{array}{c}0 \\ -\frac{\varphi_{m}}{L_{q}}\end{array}\right]+\left[\begin{array}{c}\frac{v_{d}}{L_{d}} \\ \frac{v_{q}}{L_{q}}\end{array}\right]$

Electromagnetic torque can be simplified as expressed in Eq. (10) by using the current components of $i_{d}$ and $i_{q}$ on the rotor reference plane.
$T_{e}=\frac{3}{2} \frac{P}{2}\left[\varphi_{m} i_{q}+\left(L_{d}-L_{q}\right) i_{q} i_{d}\right]$

where $P$ indicates the number of poles. As can be seen from Eq. (10), rotor magnetic flux of the torque generated by the motor depends on $i_{d}$ and $i_{q}$ currents. Mechanical equation of the motor is given as:

$$
T_{e}=J \frac{2}{P} \frac{\mathrm{d} \omega_{r}}{\mathrm{~d} t}+B \frac{2}{P} \omega_{r}+T_{L}
$$

Eq. $(8) \div(10)$ are mathematical equations of the Permanent Magnet Synchronous Motor. PMSM model was created in MATLAB Simulink by using these equations as shown in Fig. 5.

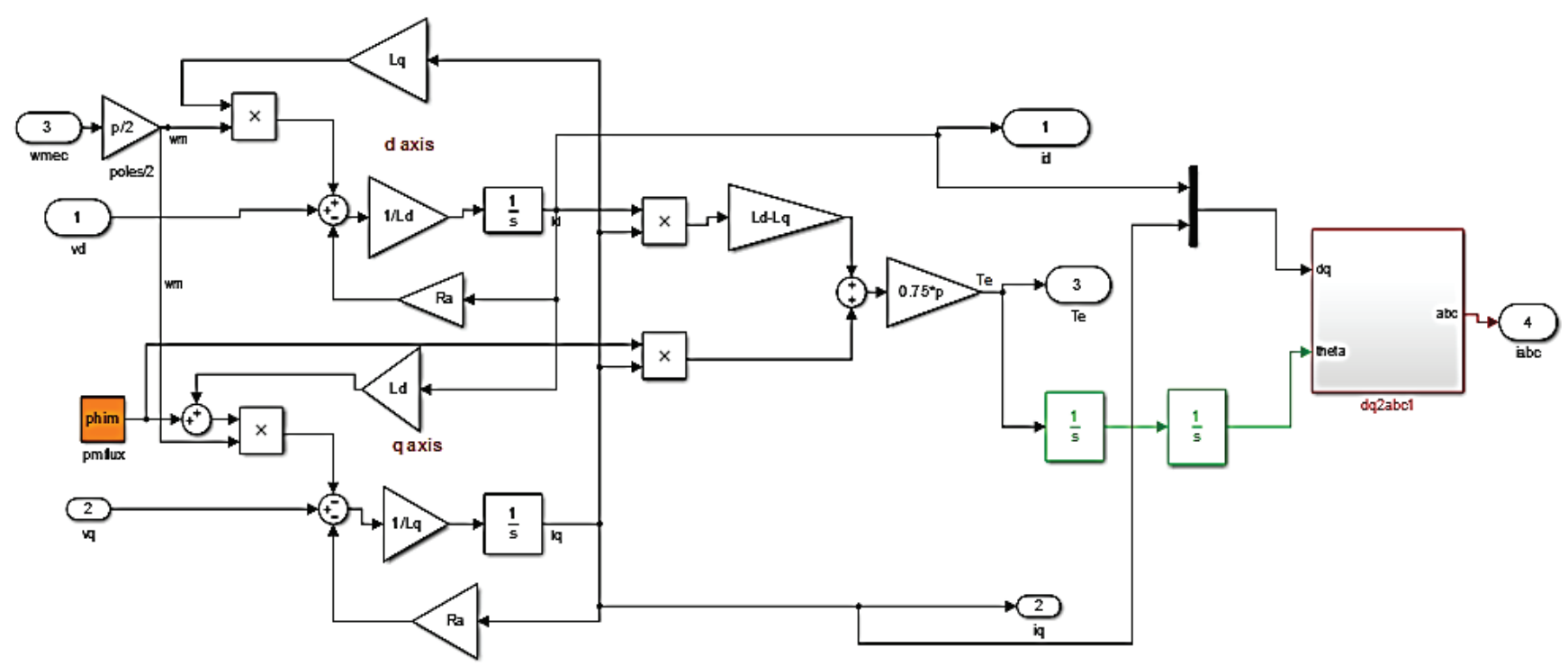

Figure 5 Simulink model of the PMSM

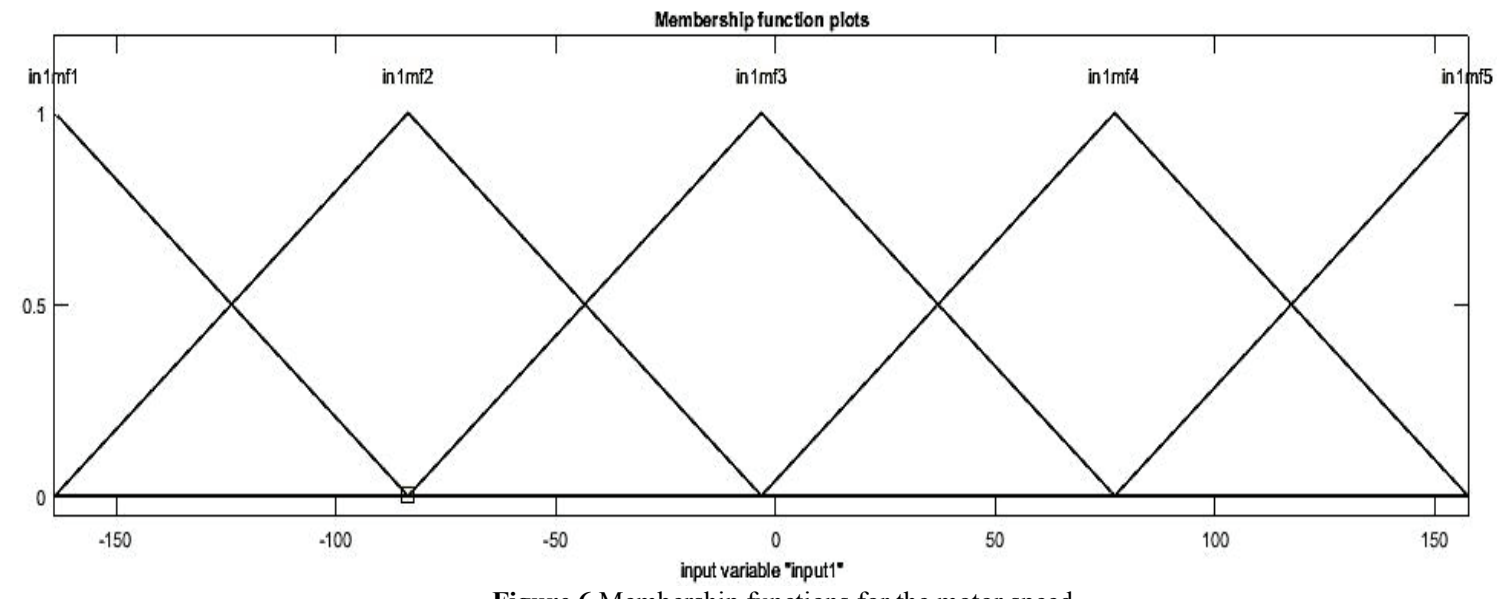

Figure 6 Membership functions for the motor speed

\section{ANFIS algorithm}

ANFIS learning algorithm is a hybrid learning algorithm involving the combined use of the least squares method and back-propagation learning algorithm. ANFIS structure can be defined as a network of Sugeno-type fuzzy systems with neural learning capabilities. The network structure is made up of layered nodes, each of which is assigned with a different function.
Prior to creating a system in which ANFIS will be used, this model is simulated in a simulation environment. In this paper, dual permanent magnet synchronous motor models fed from the matrix converter are simulated in MATLAB/Simulink. The information to be trained for the ANFIS module is the speed of PMSM. The speed information is obtained from the simulation for the ANFIS module. MATLAB calls the speed information to be trained from the workspace. The number of input 
membership functions and function types are determined from the retrieved data. In the study, 5 membership functions given in Fig. 6 are created with Trimpf method. ANFIS structure is introduced and 5 triangular input membership functions entered to the system with Sugeno model are determined together with their limits, and then rules are created. These rules are created in MATLAB Fuzzy Toolbox with membership functions by using Sugeno method and AND method. Output data are obtained in ANFIS editor by neural fuzzy training.

\section{Modelling of dual PMSMs}

Mathematical model of the PMSM used in MATLAB Simulink is based on the $\mathrm{d}-\mathrm{q}$ model of rotating reference frame. Fig. 7 shows the block diagram of parallel connected two PMSMs fed by a single three-phase matrix converter.

Zone routing control is used in the simulation. The model is created by using the average value of the current and speed information of dual PMSMs. Incompatibility occurs between the current and speed of both machines under unbalanced load conditions. In order to prevent such a problem, current and speed of the machine are averaged and then vector control of the system is implemented. The mean values of the current and speed of the machines are given in Eq. (11) and Eq. (12), respectively.

$$
\begin{aligned}
& i=\frac{i_{1}+i_{2}}{2} \\
& \omega=\frac{\omega_{1}+\omega_{2}}{2}
\end{aligned}
$$

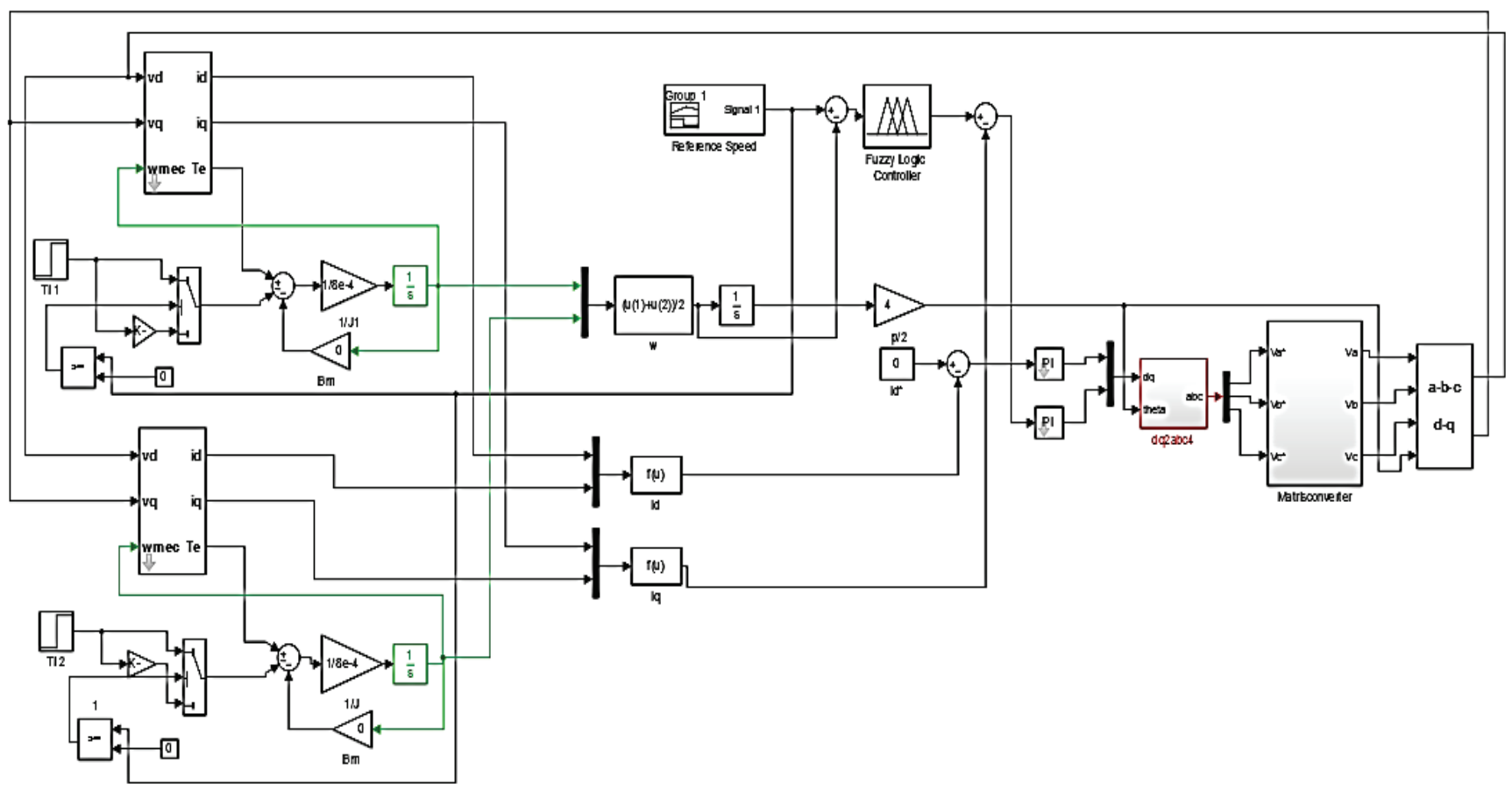

Figure 7 The simulation block diagram of vector controlled dual permanent magnet synchronous motors fed by the matrix converter with neural fuzzy controller applying the average current method.

The aim of zone routing control is to maintain the amplitude of rotor current vector in a fixed angle with respect to the stator current vector. Torque component of the PMSM current, $i_{q}$ is used. The interaction between rotor flux and stator current will generate electromagnetic torque. This interaction can be expressed as a complex flux and current phasor. Torque and flux information in the simulation is obtained by using $i_{q}$ and $i_{d}$ phasors. Controllers are used for generating the $q$ axis reference current. Actual speed is compared with the reference speed and then the resulting speed error information is controlled by the speed controller to generate torque reference. $q$ axis reference current is generated by the calculation of torque current.

If the parallel motors have equal torque load, the speeds of both motors will exhibit the same characteristics as each motor will show the same operating characteristics. In these systems, motor speeds may vary as a result of the separate effects of load changes on the motors. With the average speed method, motor speeds are not affected from this load change and catch the reference speed although they are operated under different load conditions. On the other hand, when a fault occurs in the electrical or mechanical part of any of the motors, the whole parallel-connected system is likely to be faulty as well. In this case, the fault should be removed by a control to restore the parallel-connected system to its original operating condition. The vector control of the dual permanent magnet synchronous motors fed from the matrix converter by the average phase currents method was simulated in MATLAB Simulink.

The system is basically composed of three parts: Controller, converter and motor. In this study, the motor speed is controlled with the ANFIS-based neural fuzzy controller. Average stator phase currents of the permanent magnet synchronous motor are compared with the reference phase currents. Common angular position is obtained by using the average speed of PMSMs. Initial 
angular positions are considered equal. All parameters of Motor 1 and motor 2 are equal. Each motor is operated under a different load condition. Speed, currents and torques of the motors are observed for various load conditions. Forward and backward operating of the motors working at variable speeds are also observed.

\section{Simulation results}

The simulation was performed under two different operating conditions. Matrix converter has a modulation frequency of $5 \mathrm{kHz}$ and the dual PMSMs are identical motors with $1.1 \mathrm{~kW}$ power and $3 \mathrm{~N} \cdot \mathrm{m}$ rated torque. The parameters of the PMSM are given in Appendix.

\subsection{Case I}

Simulation is performed for 4 seconds. One of the identical motors is operated on no-load, while the other motor is operated at $3 \mathrm{~N} \cdot \mathrm{m}$ rated load torque. Simulation results are given in Fig. 8 where the speed, torque, $i_{q}$ current waveforms for dual motors and output line voltage of the matrix converter and motor currents are shown. The first motor follows the variable reference speed while operating on no-load (Fig. 8a). In Fig. 8b, torque component of the motor current shows that the motor does not draw any current in steady-state due to no-load operation. The second motor connected parallel to the output of the matrix converter with the first motor is loaded with the rated torque of $3 \mathrm{~N} \cdot \mathrm{m}$. The speed of the motor reaches its variable speed reference within a short time (Fig. 8e). Value of $i_{d}$ current is maintained at zero, while $i_{q}$ current takes a value proportional to the load torque (Fig. 8g).

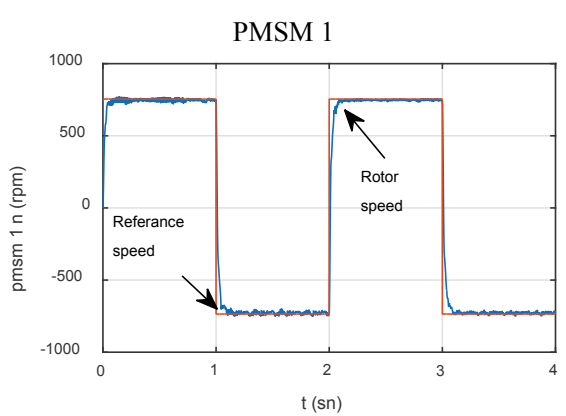

(a)

PMSM 1

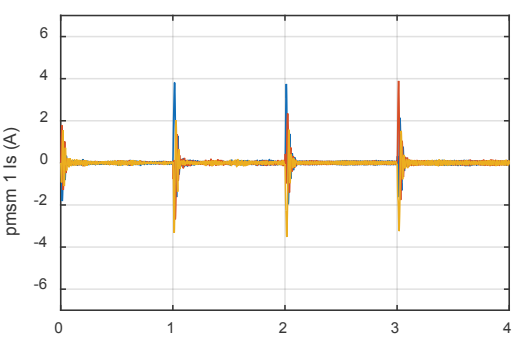

(d)

PMSM 2

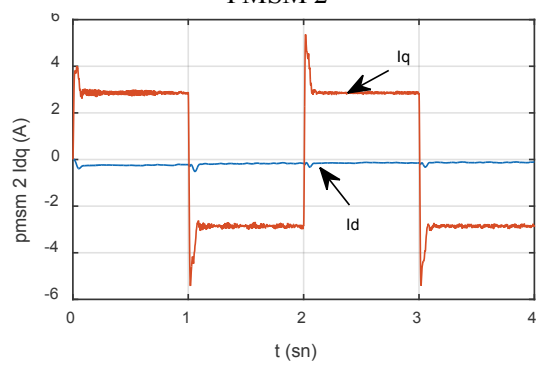

(g)

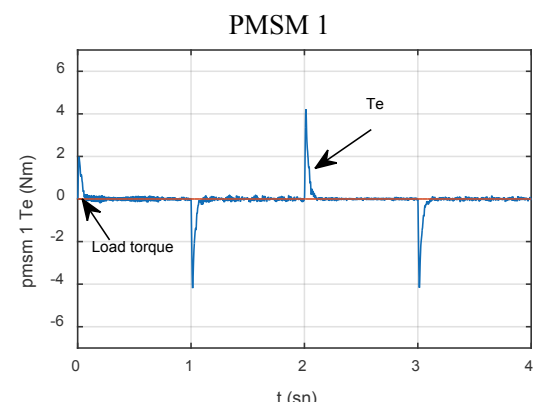

(b)

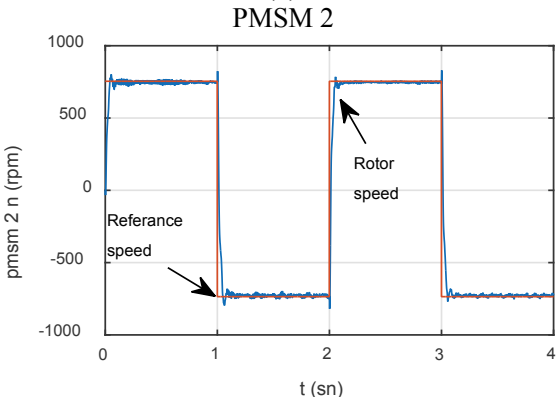

(e)

PMSM 2

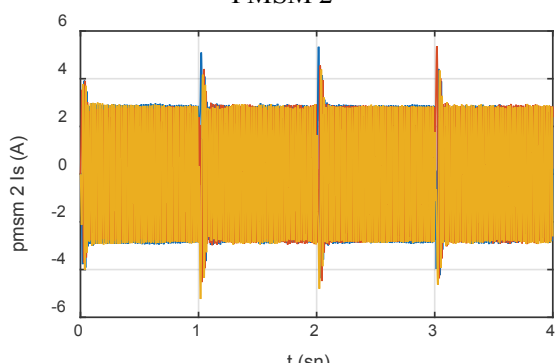

(h)

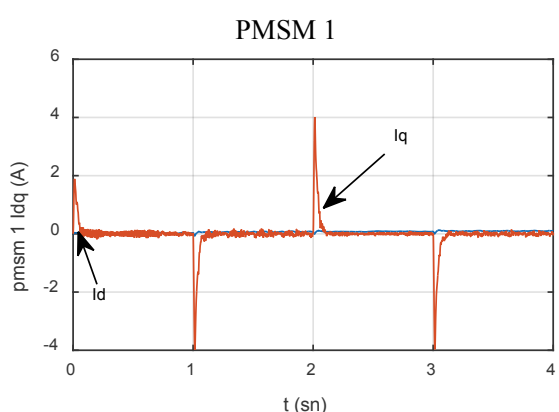

(c)

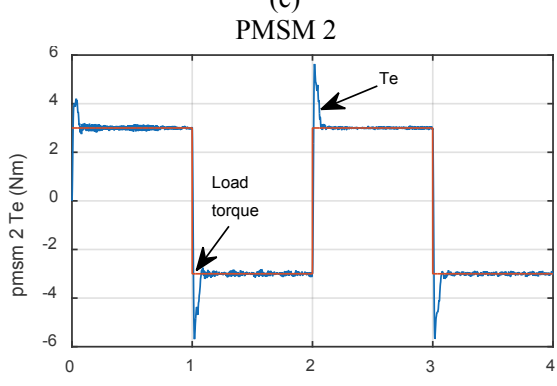

$\mathrm{t}(\mathrm{sn})$

(f)

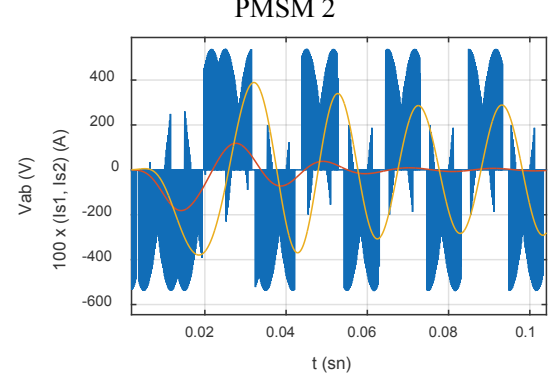

(i)

Figure 8 Simulation results for Case 1:Waveforms for PMSM 1; (a) Speed, (b) Torque, (c) $I_{\delta} \subset I_{q}$ currents, (d) Stator currents. Waveforms for PMSM 2; (e) Speed, (f) Torque, (g) $I_{d}-I_{q}$ currents, (h) Stator currents. (i) Output line voltage of matrix converter together with the stator currents of both motors.

\subsection{Case Il}

In this operating condition, one of the parallelconnected motors has been operated with $2 \mathrm{~N} \cdot \mathrm{m}$ load torque during the $1^{\text {st }}$ second and then for the rest of the period the load torque is increased to the rated value of 3 $\mathrm{N} \cdot \mathrm{m}$ at the instant of $2^{\text {nd }}$ second where the speed reversal command is also given. For the first two seconds the second motor has been loaded with $3 \mathrm{~N} \cdot \mathrm{m}$ and then this rated torque was reduced to $1 \mathrm{~N} \cdot \mathrm{m}$ for the rest of the period. The relevant simulation waveforms for both motors are shown in Fig. 9. 


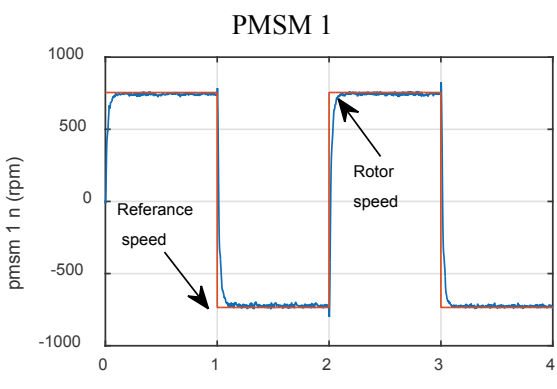

(a)

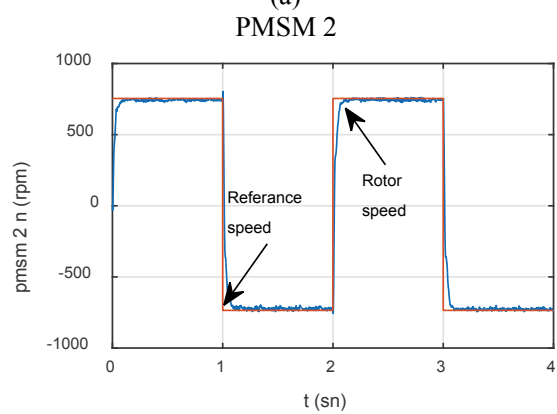

(d)
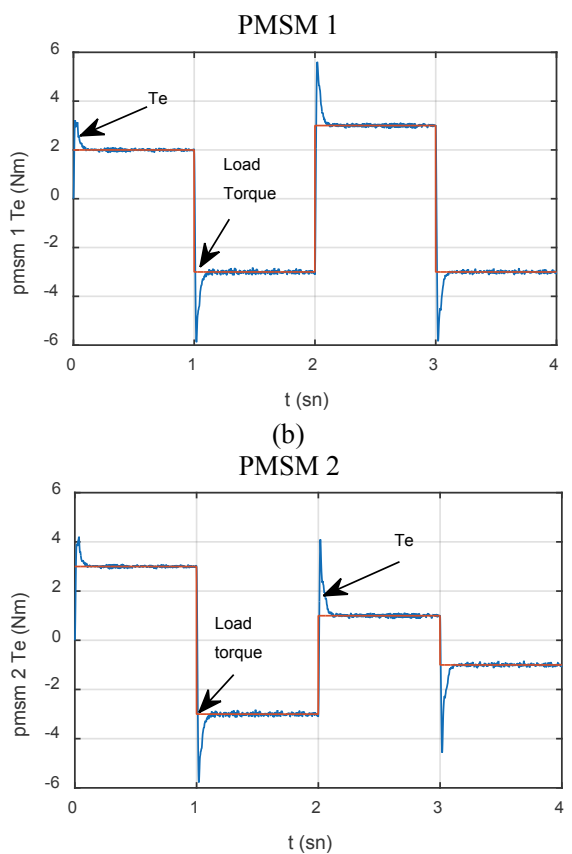

(e)

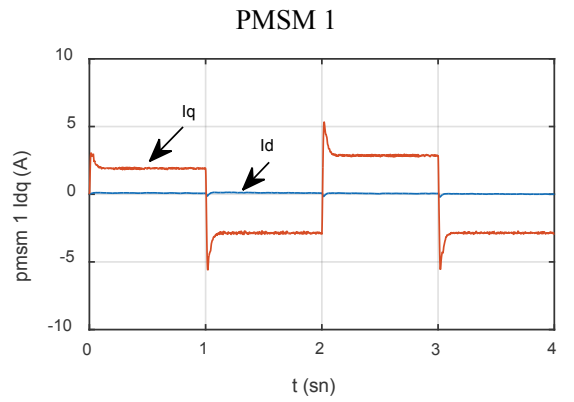

(c)

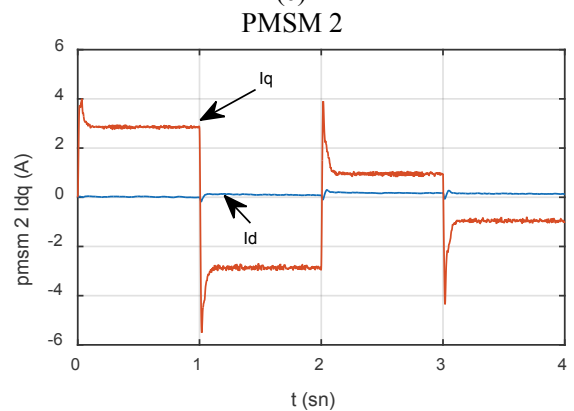

(f)

Figure 9 Simulation results for Case 2: Waveforms for PMSM 1; (a) Speed, (b) Torque, (c) $I_{d}-I_{q}$ currents. Waveforms for PMSM 2; (d) Speed, (e) Torque, (f) $I_{d}-I_{q}$ currents.

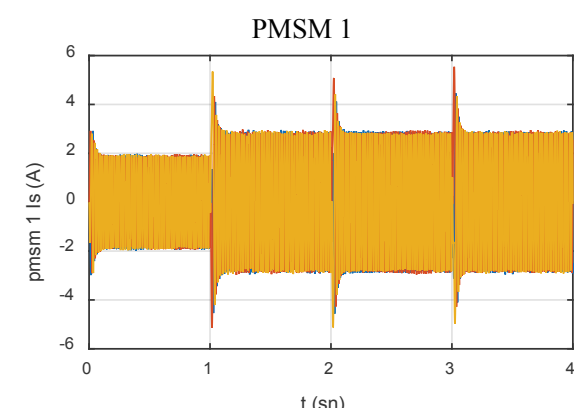

(a)

PMSM 2

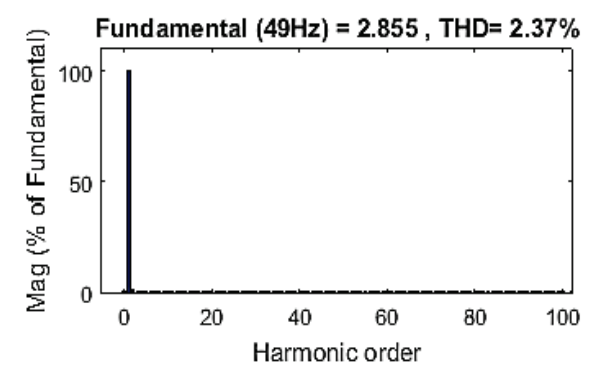

(d)
PMSM 1

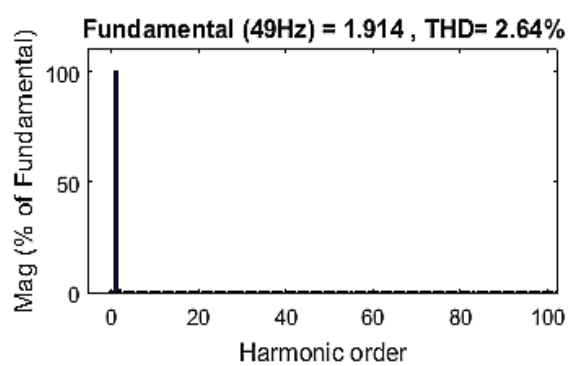

(b)

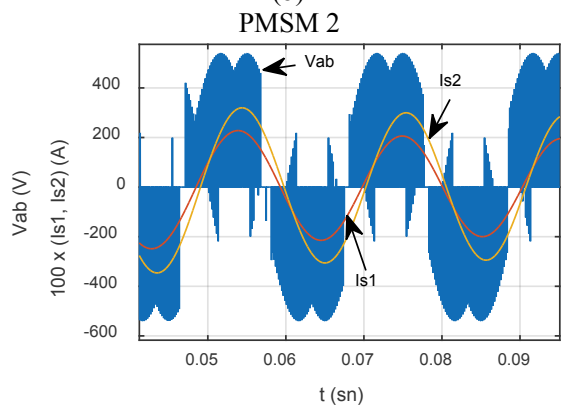

(e)

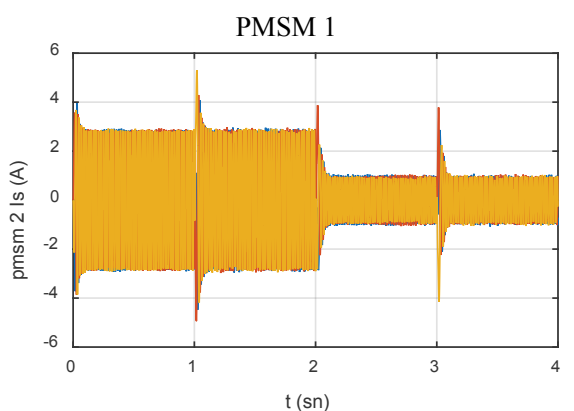

(c)

Figure 10 Simulation results for case II: Waveforms for PMSM 1; (a) Current, (b) Harmonic spectrum of current, (c) Output line voltage of matrix converter together with the stator currents. Waveforms for PMSM 2; (d) Current, (e) Harmonic spectrum of current.

Fig. 10 shows the stator currents for whole period (4 seconds). Harmonic spectrum of the motor currents, output line voltage of the matrix converter together with the stator current in detail (for two output period) for dual motors are also illustrated in Fig. 10. The converter output voltage and the motor currents are also given in Fig. 10e. It is observed that dual motors have currents proportional to their torque for various conditions despite being fed from the same converter.

\section{Conclusion}

In this study, a drive system which consists of dual permanent magnet synchronous motors fed by a threephase matrix converter has been modelled and simulated. ANFIS controller is used instead of classical controller. ANFIS-based neural fuzzy controller is observed to catch the phase information within a short time despite the load changes in the system. In the model a common angular position was obtained by considering the average speed of the dual PMSMs. In order to prevent disconformities between currents and speeds of both machines under 
various load conditions, the vector control technique was implemented by taking average of the currents and speeds of both machines. This technique shows that it has good adaptation with load variation. Since the threephase matrix converter used in this work provides direct ac-ac conversion in a single step and allows bidirectional power flow it was possible to operate the PMSMs in all four regions. Simulation results have been taken for different load conditions. First, one of the PMSMs was operated on no-load and the other one was operated at the rated torque. Then, the PMSMs were loaded with different loads. In both cases the speeds of the PMSMs followed the reference speed and the generated torque of each motor met the load torque meanwhile providing the same speed. The simulation results show good performance of the drive system.

Motor Paremeters: The ratings of the three phase 50 $\mathrm{Hz}, 220 \mathrm{~V}, 750 \mathrm{rpm}$ permanent magnet synchronous motor are: $P=1.1 \mathrm{~kW}, R_{\mathrm{a}}=2.875 \Omega, L_{\mathrm{d}}=8.5 \mathrm{mH}, L_{\mathrm{q}}=$ $8.5 \mathrm{mH}, J=0.0222 \mathrm{~kg} \cdot \mathrm{m}^{2}, B=0 \mathrm{~N} \cdot \mathrm{m} \cdot \mathrm{s} / \mathrm{rad}, P=8$ poles.

\section{References}

[1] Beasant, R. R.; Beattie, W. C.; Refsum, A. An Approach to The Realization of a High-power Venturini Converter. // Proc. IEEE PESC '90. (1990), pp. 291-297. https://doi.org/10.1109/PESC.1990.131201

[2] Alesina, A.; Venturini, M. G. B. Analysis and Design of Optimum-Amplitude Nine-Switch Direct AC-AC Converters. // IEEE Trans. Power Electron. 4, 1(1989), pp. 101-112. https://doi.org/10.1109/63.21879

[3] Bauer, J.; Fligl, S.; Steimel, A. Design and Dimensioning of Essential Passive Components for the Matrix Converter Prototype. // Automatika. 53, 3(2012), pp. 225-235. https://doi.org/10.7305/automatika.53-3.134

[4] Sünter, S. A Vector Controlled Matrix Converter Induction Motor Drive. The University of Nottingham, 1995.

[5] Iyer, N. P. R. Carrier Based Modulation Technique for Three Phase Matrix Converters - State of the Art Progress. // Proc. - 2010 IEEE Reg. 8 Int. Conf. Comput. Technol. Electr. Electron. Eng. Sib., (2010) pp. 659-664.

[6] Sünter, S.; Altun, H. Control of a Permanent Magnet Synchronous Motor Fed by a Direct AC-AC Converter. Electr. Eng. 87, 2(2005), pp. 83-92. https://doi.org/10.1007/s00202-004-0226-6

[7] Rasmussen, H. D. Adaptive Observer for Speed Sensorless PM Motor Control. // Aalborg. 2(2003), pp. 599-603.

[8] Zadeh, L. A. Fuzzy Sets. // Inf. Control. 8, 3(1965), pp. 338-353. https://doi.org/10.1016/S0019-9958(65)90241-X

[9] Jyh Shing, E. M.; Jang, R., Sun, C. T.Neuro-Fuzzy and Soft Computing: A Computational Approach to Learning and Machine Intelligence. New Jersey: Inggris, 1997.

[10] Jang, R. ANFIS: Adaptive-Network-Based Fuzzy Inference System. // IEEE Trans. Syst. Man Cybern. 23, 3(1993), pp. 665-685. https://doi.org/10.1109/21.256541

[11] Bidart, D.; Pietrzak David, M.; Maussion, P.; Fadel, M. Mono Inverter Dual Parallel PMSM - Structure and Control Strategy. / Proc. - $34^{\text {th }}$ Annu. Conf. IEEE Ind. Electron. Soc. IECON 2008, (2008), pp. 268-273.
[12] Lazi, J. M.; Ibrahim, Z.; Talib, M. H. N.; Mustafa, R. Dual Motor Drives for PMSM Using Average Phase Current Technique. // PECon2010 - 2010 IEEE Int. Conf. Power Energy, (2010), pp. 786-790.

[13] Drive, D. S.; Del Pizzo, A.; Iannuzzi, D.; Spina, I. Optimum Torque. // Current Control of Electr. Eng. 14, 1(2010), pp. 61-66.

[14] Nguyen, N. L.; Fadel, M.; Llor, A. A New Approach to Predictive Torque Control with Dual Parallel PMSM system. // Proc. IEEE Int. Conf. Ind. Technol., (2013), pp. 1806-1811.

[15] Bidart, D.; PietrzakDavid, M.; Maussion, P.; Fadel, M. Mono Inverter Multi-parallel Permanent Magnet Synchronous Motor: Structure and Control Strategy. // IET Electr. Power Appl. 5, 3(2011), pp. 288-294. https://doi.org/10.1049/iet-epa.2010.0180

[16] Asri, A.; Ishak, D.; Iqbal, S.; Kamarol, M. A Speed Sensorless Field Oriented Control of Parallel- Connected Dual PMSM. // 2011 IEEE Int. Conf. Control Syst. Comput. Eng. ICCSCE 2011, (2011), pp. 567-570.

[17] Benteşen Yakut, Y.; Sünter, S.; Özdemir, M. Comparation of PI and Neural Fuzzy Based Closed Loop Control Methods for Permanent Magnet Synchronous Motor Fed by Matrix Converter. // ACEMP-Optim-Electromotion 2015 Jt. Conf., (2015), pp. 399-405.

\section{Authors' addresses}

Yurdagül Benteşen Yakut, PhD. Eng. Lecturer

Dicle University Engineering,

Faculty Department of Electrical and Electronics Engineering, 21280 Diyarbakır, Turkey

bentesen@dicle.edu.t

Sedat Sünter, PhD. Eng. Professor

Firat University Engineering,

Faculty Department of Electrical and Electronics Engineering, 23119 Elazı ̆̆, Turkey

ssunter@firat.edu.tr

\section{Mehmet Özdemir, PhD. Eng. Assistant Professor}

Firat University Engineering,

Faculty Department of Electrical and Electronics Engineering,

23119 Elazı̆̆, Turkey

mozdemir@firat.edu.tr 